University of Nebraska - Lincoln

DigitalCommons@University of Nebraska - Lincoln

1991

\title{
Molecular Epidemiologic Techniques in Analysis of Epidemic and Endemic Shigella dysenteriae Type 1 Strains
}

\author{
Nancy A. Strockbine \\ Centers for Disease Control \\ Julie Parsonnet \\ Centers for Disease Control \\ Katherine Greene \\ Centers for Disease Control \\ Julia A. Kiehlbauch \\ Centers for Disease Control \\ I. Kaye Wachsmuth \\ Centers for Disease Control
}

Follow this and additional works at: https://digitalcommons.unl.edu/publichealthresources

Part of the Public Health Commons

Strockbine, Nancy A.; Parsonnet, Julie; Greene, Katherine; Kiehlbauch, Julia A.; and Wachsmuth, I. Kaye, "Molecular Epidemiologic Techniques in Analysis of Epidemic and Endemic Shigella dysenteriae Type 1 Strains" (1991). Public Health Resources. 228.

https://digitalcommons.unl.edu/publichealthresources/228

This Article is brought to you for free and open access by the Public Health Resources at DigitalCommons@University of Nebraska - Lincoln. It has been accepted for inclusion in Public Health Resources by an authorized administrator of DigitalCommons@University of Nebraska - Lincoln. 


\title{
Molecular Epidemiologic Techniques in Analysis of Epidemic and Endemic Shigella dysenteriae Type 1 Strains
}

\author{
Nancy A. Strockbine, Julie Parsonnet, \\ Katherine Greene, Julia A. Kiehlbauch, \\ and I. Kaye Wachsmuth
}

Enteric Diseases Branch, Division of Bacterial Diseases, Center for Infectious Diseases, Centers for Disease Control, Atlanta, Georgia

\begin{abstract}
During 1988 the number of Shigella dysenteriae type 1 infections reported in the United States increased fivefold. To determine if recent isolates from Mexico were related to those that caused epidemics of dysentery worldwide, Southern hybridization analysis was done with Shiga toxin and ribosomal RNA gene probes. Western hemisphere and Eastern Hemisphere strains differed by the size of a single EcoRI fragment carrying the Shiga toxin genes. Three ribosomal DNA (rDNA) patterns were observed, which correlated with the strain's continental origin for 81 of 83 isolates tested. Together the Shiga toxin and rDNA probe results indicated that recent Mexican isolates were chromosomally similar to earlier Central American isolates and distinct from Asian and African strains. This suggests there has been no significant exchange of organisms between continents in recent decades and that the 1988 outbreak in Mexico was caused by strains present in Central America since at least 1962.
\end{abstract}

Shigella dysenteriae type 1 (Shiga bacillus) has been a cause of endemic and epidemic dysentery worldwide. Since 1960, major epidemics in Central America, Mexico, central Africa, and the Indian subcontinent resulted in an estimated 1 million cases and thousands of deaths. Factors affecting the emergence and decline of epidemics due to $S$. dysenteriae type 1 are not well understood; however, shigellae are believed to have only a human or primate host and must continue at a low level in the population or be reintroduced from another source between epidemics.

Parsonnet et al. [1] reported a fivefold increase in the number of $S$. dysenteriae type 1 infections in the United States (US); 44 of 47 infected persons from whom travel histories were obtained had traveled to Mexico. Plasmid profiles and antibiotic resistance patterns revealed two dominant strains, one from the Yucatan Peninsula and one from northern Mexico. During the investigation, the following questions were raised: Was the epidemic strain related to strains previously isolated in Mexico and Central America or was a new outside strain introduced? Were the strains that caused disease among US travelers to the Yucatan Peninsula similar and were they related to isolates from travelers to other areas of Mexico? The objective of this study was to characterize the recent Mexican isolates and compare them with each other and with isolates from the earlier pandemic in Central America and other parts of the world.

Received 29 May 1990; revised 13 August 1990.

Reprints or correspondence: Dr. Nancy A. Strockbine, Enteric Diseases Laboratory Section, MS CO3, Centers for Disease Control, Atlanta, GA 30333.

The Journal of Infectious Diseases 1991;163:406-409 This article is in the public domain. 0022-1899/91/6302-0033

\section{Materials and Methods}

Bacteria. Eighty-three isolates of $S$. dysenteriae type 1 were examined. State health departments were asked to send 1988 isolates of $S$. dysenteriae type 1 to the Centers for Disease Control (CDC); 40 isolates were received. Among these were 29 from US travelers who visited the Yucatan Peninsula between December 1987 and December 1988 and 11 from persons who visited other parts of Mexico in 1988. Nine 1988 isolates from residents of Mexico were contributed by the Mexican Ministry of Health, and one 1988 isolate, from a Guatemalan citizen, was contributed by the Institute of Nutrition of Central America and Panama. In addition, 33 isolates from the CDC culture collection dating from 1962 to 1988 were studied. Of these, four from Thailand, two each from Rwanda (1987) and Zaire, one each from Guatemala and El Salvador, and three from Mexico (obtained between 1969 and 1972) were recovered during outbreaks in the respective countries. The remaining isolates were not known to come from outbreaks of dysentery. Dates of isolation and origins are shown in table 1 .

Plasmid profiles. Plasmid DNA was isolated from all $1988 \mathrm{Mex}-$ ican and Guatemalan isolates and from selected strains from the reference collection as described by Birnboim and Doly [2] with the following modifications: $4 \mathrm{mg} / \mathrm{ml}$ of lysozyme rather than $2 \mathrm{mg} / \mathrm{ml}$ was used to disrupt the cell walls and two rather than three ethanol precipitations were done. Precipitated plasmid DNA was resuspended in $50 \mu$ of TE ( $0.01 M$ Tris- $\mathrm{HCl}, \mathrm{pH} 8.0$, containing 0.001 $M$ EDTA) and separated on a $0.85 \%$ (wt/vol) agarose gel, stained with ethidium bromide $(1 \mu \mathrm{g} / \mathrm{ml})$ and photographed under UV illumination.

Antibiograms. Antimicrobial susceptibility testing was done by the modified Kirby and Bauer method [3] with chloramphenicol, trimethoprim, trimethoprim-sulfamethoxazole, tetracycline, sulfisoxazole, ampicillin, carbenicillin, streptomycin, and kanamycin.

Southern blot analysis. Southern blot analysis was done on all 83 isolates. Total cellular DNA was extracted according to the method of Owen and Boreman [4] or Maniatis et al. [5]. Southern transfer of DNA and DNA-DNA hybridizations were done as described by Maniatis et al. [5]. DNA-RNA hybridizations were done as described by Altwegg et al. [6]. The 1142-bp Shiga toxin/Shiga-like toxin I 
Table 1. Shigella dysenteriae type 1 cultures studied.

\begin{tabular}{|c|c|c|c|}
\hline Origin, date & No. of isolates & $\begin{array}{l}\text { Shiga toxin } \\
\text { fragment* }\end{array}$ & rDNA pattern ${ }^{\dagger}$ \\
\hline Bangladesh, 1984 & 4 & 4.3 & B \\
\hline El Salvador, 1970 & 1 & 5.1 & A \\
\hline \multicolumn{4}{|l|}{ Guatemala } \\
\hline 1962 & 1 & 5.1 & A \\
\hline 1969 & 1 & 5.1 & A \\
\hline 1981 & 1 & 5.1 & A \\
\hline 1988 & 1 & 5.1 & A \\
\hline \multicolumn{4}{|l|}{ India } \\
\hline 1980 & 1 & 4.3 & A \\
\hline 1988 & 5 & 4.3 & B \\
\hline \multicolumn{4}{|l|}{ Mexico } \\
\hline 1971 & 1 & 5.1 & A \\
\hline 1972 & 2 & 5.1 & A \\
\hline 1984 & 1 & 5.1 & A \\
\hline 1988 & 49 & 5.1 & A \\
\hline \multicolumn{4}{|l|}{ Nepal } \\
\hline 1984 & 1 & 4.3 & B \\
\hline 1988 & 1 & 4.3 & B \\
\hline \multicolumn{4}{|l|}{ Rwanda } \\
\hline 1984 & 1 & 4.3 & $\mathrm{C}$ \\
\hline 1987 & 2 & 4.3 & $\mathrm{C}$ \\
\hline \multicolumn{4}{|l|}{ Saudi Arabia } \\
\hline 1985 & 1 & 4.3 & B \\
\hline 1988 & 1 & 4.3 & B \\
\hline Sudan, 1985 & 1 & 4.3 & A \\
\hline Thailand, 1987 & 5 & 4.3 & B \\
\hline Zaire, 1981 & 2 & 4.3 & $\mathrm{C}$ \\
\hline
\end{tabular}

* Size (kb) of EcoRI fragment carrying Shiga toxin genes (figure 1A).

$\dagger$ rDNA pattern generated with $P v u$ II (figure 1B).

probe constructed by Newland and Neill [7] was labeled by random priming with $\alpha\left[{ }^{32} \mathrm{P}\right] \mathrm{dCTP}$ and used to detect the Shiga toxin genes in EcoRI-restricted total cellular DNA preparations. 16S and 23S ribosomal (r) RNAs from Escherichia coli (Boehringer Mannheim, Indianapolis) were purified by high performance liquid chromatography, partly hydrolyzed in $10 \mathrm{mM}$ Tris- $\mathrm{HCl}, \mathrm{pH} \mathrm{9.5,} \mathrm{for} 5 \mathrm{~min}$, and quickly cooled on ice. The fragments generated were then labeled with $\left.\gamma{ }^{32} \mathrm{P}\right]$ ATP and polynucleotide kinase (Bethesda Research Laboratories, Gaithersburg, MD) as described by Maizels [8] and used to detect homologous sequences in PvuII-restricted cellular DNA preparations.

\section{Results}

Five distinct plasmid profiles and seven different antibiotic sensitivity patterns were observed among the 40 isolates from US tourists to Mexico and 10 isolates from residents of Mexico and Guatemala (data not shown). Plasmid profiles and antibiograms of the isolates from the tourists have been described elsewhere [1]. Most isolates from visitors to and seven of eight isolates from residents of the Yucatan had the same plasmid profile (120-, 80-, 6-, and 2-MDa plasmids) and antibiotic susceptibility patterns (resistance to chloramphenicol, tetracycline, sulfisoxazole, and streptomycin) as two isolates obtained from El Salvador and Mexico in the 1970s. Two other Central American isolates from 1969 and 1972 had similar plasmid profiles but lacked the 120- to 140-MDa invasion plasmid. Plasmid profiles from four African and four Asian isolates were distinct from those from the western hemisphere and, with the exception of isolates from Bangladesh and Thailand, were distinct from each other.

All isolates from Mexico and Central America $(n=50)$ carried the Shiga toxin genes on a 5.1-kb EcoRI chromosomal fragment (figure 1A; table 1). No difference was observed between the recent Yucatan and non-Yucatan isolates or between those from North and Central America isolated before 1988. All isolates from Africa and Asia $(n=33)$ carried the Shiga toxin genes on a 4.3-kb EcoRI fragment (figure 1A; table 1). Neill et al. [9] also reported two EcoRI fragments, one each of 4.3 and $5.1 \mathrm{~kb}$, but did not list the geographic origins of most of their isolates.

With PvuII, three rDNA patterns, designated A, B, and C (figure $1 \mathrm{~B})$, resulting from restriction fragment length polymorphisms in the rRNA genes were observed among the 83 isolates. A collection of 20 isolates from Central America, Africa, and Asia was tested several times with the rRNA probe and the rDNA patterns were found to be reproducible. Regardless of location and time of isolation, the rRNA genes in isolates from Mexico and Central America were organized like pattern A. The rRNA genes in 18 of 19 isolates from Asia were organized like pattern B, and the rRNA genes in five of six isolates from Africa were organized like pattern $C$. The rRNA genes in one isolate from Asia (India 1980) and one from Africa (Sudan 1985) were like pattern A.

Six potential combinations of the two Shiga toxin and three rDNA profiles were possible. Among the 83 isolates tested, we observed four different combinations of traits: 5.1- and 4.3$\mathrm{kb}$ toxin fragments associated with rDNA pattern A (58 and 2 isolates, respectively); $4.3-\mathrm{kb}$ toxin fragment associated with rDNA pattern $\mathrm{B}$ (18 isolates); and 4.3-kb toxin fragment associated with $\mathrm{rDNA}$ pattern $\mathrm{C}$ (5 isolates). No 5.1-kb Shiga toxin fragments were associated with patterns $\mathrm{B}$ or $\mathrm{C}$.

\section{Discussion}

Data from plasmid profile and antibiotic susceptibility studies demonstrated the presence of at least eight different strains of $S$. dysenteriae type 1 within Mexico and Guatemala during 1988. Most Yucatan isolates had plasmid profile and antibiotic susceptibility patterns similar to those of selected strains isolated during the 1969-1972 pandemic.

From our studies it was not possible to determine if the predominant Yucatan strain was more virulent, survived more efficiently in nature, or was disseminated more widely through factors unrelated to virulence than the other strains in the region. The fall and rise in herd immunity to $S$. dysenteriae type 1 has been suggested as a possible factor affecting the emergence and decline of epidemics due to this organism. 
A

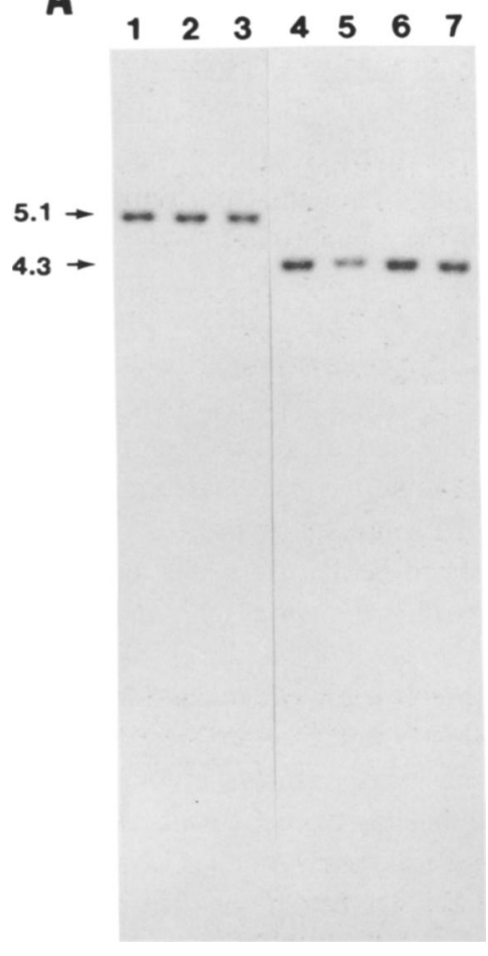

B

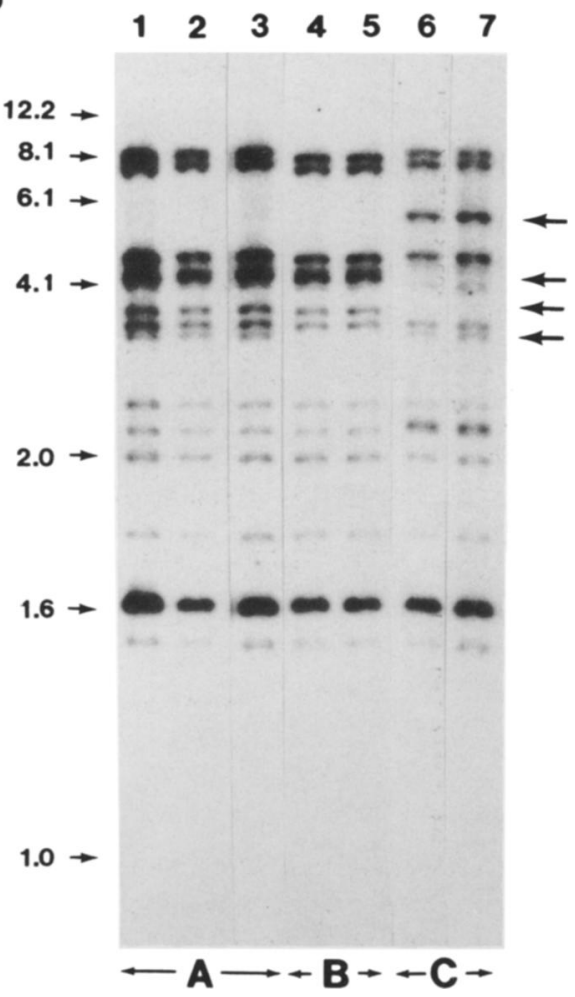

Figure 1. Southern hybridization analysis of total cellular DNA from Shigella dysenteriae type 1. A, DNA restricted with EcoRI and probed for Shiga toxin genes. B, DNA restricted with $P v u I I$ and probed for $16 \mathrm{~S}$ and $23 \mathrm{~S}$ rRNA genes. Countries of origin and isolates by lane: Guatemala 1969, 1; Mexico (non-Yucatan) 1988, 2; Mexico (Yucatan) 1988, 3; Thailand 1987, 4; India 1988, 5; Zaire 1981, 6; and Rwanda 1984, 7. Lanes 1-3, rDNA pattern A; lanes 4 and 5, pattern B; lanes 6 and 7, pattern C. Arrows at right designate bands that vary among patterns.
Although most isolates from Yucatan residents (7/8) were the same as the predominant strain detected among US tourists, our sampling of residents was not adequate to ascertain whether residents and tourists were equally susceptible to infection.

rDNA pattern A was seen primarily among American strains while patterns $\mathrm{B}$ and $\mathrm{C}$ were observed among Asian and African strains, respectively. Two strains, one from India and one from Sudan, resembled American strains by rDNA typing and strains from the Eastern hemisphere by size of the fragment carrying the Shiga toxin genes $(4.3 \mathrm{~kb})$. The mechanism(s) responsible for differences in rDNA patterns A-C is not known; however, it is possible that certain recombinational events between the rRNA genes may be favored. Strains from India and Sudan may have had rearrangement between certain rRNA genes to produce an American ribotyping pattern while the flanking sequences next to the genes for Shiga toxin remained unaffected. Alternatively, the strains may actually be genetically more similar to the American strains and have had the region of their chromosome carrying the Shiga toxin genes replaced by a similar region from an Eastern hemisphere strain. The possibility of point mutations affecting the same restriction sites surrounding the Shiga toxin or rRNA genes also cannot be excluded.

Taken together, the ribotyping and Shiga toxin data demonstrated that there has been no significant exchange of strains between Africa, Asia, and North and Central America. One explanation for this is insufficient travel by people in endemic areas to spread strains between the areas. Also, host or environmental factors may allow only particular strain(s) to predominate in a given area. The observation that the recent isolates from US tourists were chromosomally similar to strains detected earlier from Mexico and Central America argues against the possibility that the increase in $S$. dysenteriae type 1 infections in Mexico during 1988 was due to importation of a strain from outside Mexico or Central America. It is likely that the increased number of $S$. dysenteriae type 1 infections among US travelers to the Yucatan Peninsula was due to a strain already present.

\section{Acknowledgment}

We thank the California, Colorado, Georgia, Iowa, Illinois, Louisiana, Maine, Massachusetts, Missouri, New York, North Dakota, Ohio, Pennsylvania, Texas, Utah, Virginia, and Washington state health departments, the Mexican Ministry of Health, and the Institute of Nutrition of Central America and Panama for sharing $S$. dysenteriae 1 isolates with us for this study. We also thank David N. Taylor, Armed Forces Research Institute of Medical Sciences, Bangkok, Thailand, for providing us with $S$. dysenteriae type 1 isolates from Asia.

\section{References}

1. Parsonnet J, Greene K, Gerber RA, Wachsmuth K, Blake P. Shigella 
dysenteriae type 1 infections in U.S. travelers to Mexico, 1988. Lancet 1989;2:543-5.

2. Birnboim HC, Doly J. A rapid alkaline extraction procedure for screening recombinant plasmid DNA. Nucleic Acids Res 1979;7:1513-23.

3. Barry AL, Thornsberry C. Susceptibility tests: diffusion test procedures. In: Lennette EH, Balows A, Hausler WJ Jr, Shadomy HJ, eds. Manual of clinical microbiology. 4th ed. Washington, DC: American Society for Microbiology, 1985:978-87.

4. Owen RJ, Boreman P. A rapid biochemical method for purifying high molecular weight bacterial chromosomal DNA for restriction enzyme analysis. Nucleic Acids Res 1987;15:3631.

5. Maniatis T, Fritsch EF, Sambrook J. Molecular cloning. A laboratory manual. Cold Spring Harbor, NY: Cold Spring Harbor Laboratory, 1982.

6. Altwegg M, Altwegg-Bissig R, Demarta A, Peduzzi R, Reeves MW, Swaminathan B. Comparison of four typing methods of Aeromonas species. J Diarrhoeal Dis Res 1989;1:6-14.

7. Newland JW, Neill RJ. DNA probes for Shiga-like toxins I and II and for toxin-converting bacteriophages. J Clin Microbiol 1988;26:1292-7.

8. Maizels N. Dictyostelium 17S, $25 \mathrm{~S}$, and 5 S rDNAs lie within a 38,000 base pair repeated unit. Cell 1976;9:431-8.

9. Neill RJ, Gemski P, Formal SB, Newland JW. Deletion of Shiga toxin genes in a chlorate-resistant derivative of Shigella dysenteriae type 1 that retains virulence. J Infect Dis 1988;158:737-41.

\title{
Combined Use of Released Proteins and Lipopolysaccharide in Enzyme-Linked Immunosorbent Assay for Serologic Screening of Yersinia Infections
}

\author{
Outi Mäki-Ikola, Jürgen Heesemann, \\ Riitta Lahesmaa, Auli Toivanen, \\ and Kaisa Granfors
}

\author{
Departments of Medical Microbiology and Medicine, Turku University, \\ Finland; Institute of Hygiene and Microbiology, \\ University of Würzburg, Germany
}

\begin{abstract}
An ELISA for the screening of serum antibodies to Yersinia species was developed using plasmidencoded released proteins of Yersinia enterocolitica 0:8 and lipopolysaccharide of $Y$. enterocolitica 0:3 as a combined antigen. Of $\mathbf{4 3}$ sera from patients infected with one of six different Yersinia serotypes, $40(93 \%)$ were positive in this assay. When tested using six serotype-specific ELISAs with the corresponding Yersinia bacteria as antigens, $38(88 \%)$ were positive. This screening ELISA detects antibodies to all virulent yersiniae in one assay and offers the possibility for diagnosis of infections caused by Yersinia serotypes seen only occasionally and not usually included in the serotype-specific ELISAs. Thus, this ELISA offers a substantial advantage by saving time and money in routine laboratory work.
\end{abstract}

Yersinia enterocolitica and Yersinia pseudotuberculosis are important causative agents of enteric infections in man. For laboratory diagnosis, isolation of the pathogen from feces is the most reliable criterion, but it is not always successful. Yersinia infections are usually associated with a strong antibody response, and consequently, the laboratory diagnosis is often dependent on detection of specific antibodies in the serum [1-3].

Currently, serologic diagnosis of yersiniosis is made primarily by ELISA [1] or the tube agglutination test [3]. Separate quantitation of serotype-specific Yersinia antibodies of different immunoglobulin classes is considered important [1, $2,4]$ and especially valuable in the retrospective diagnosis of yersiniosis as a cause of reactive complications, when isolation of the organism is no longer possible. However, the mul-

Received 6 March 1990; revised 29 June 1990.

Grant support: Yrjö Jahnsson Foundation, Rheumatism Research Foundation, Finnish Cultural Foundation, Research and Science Foundation of Farmos, Finnish Medical Society Duodecim, and Sigrid Jusélius Foundation.

Reprints or correspondence: Dr. Outi Mäki-Ikola, Department of Medical Microbiology, Turku University, SF-20520 Turku, Finland.

The Journal of Infectious Diseases 1991;163:409-412

(c) 1991 by The University of Chicago. All rights reserved.

0022-1899/91/6302-0034\$01.00 tiple Yersinia serotypes and their wide antigenic diversity has made the routine antibody testing laborious because antibodies must be tested separately against various common serotypes.

Human-pathogenic strains of the genus Yersinia possess closely related plasmids of $\sim 42-46 \mathrm{mDa}$ that control virulence functions [5, 6]. Several polypeptides encoded by these virulence-associated plasmids have been identified as outer membrane proteins $[5,6]$. When grown in calcium-deficient conditions, the low-molecular-weight proteins are extensively released into the culture medium $[5,7]$. These released proteins (RPs) are expressed in vivo, and both patients and animals produce antibodies against them during Yersinia infection [4, 6, 8-11]. Immunochemical analysis has demonstrated that RPs of different Yersinia species are similar in molecular mass and antigenically [5-7, 10,11]. With this in mind, we studied the possibility of using these RPs as screening antigens in ELISAs for the routine serologic diagnosis of Yersinia infections.

\section{Patients and Methods}

Antigen preparation. The strains used in serotype-specific routine ELISAs included $Y$. enterocolitica O:3, O:5, and O:9 and $Y$. pseudotuberculosis I, II, and III. All clinical stool isolates were cul- 